\title{
Analysis of Factors Affecting the Quality of the Annual Development Plan of Aceh Tamiang Regency
}

\author{
Yohny Anwar ${ }^{1}$, Ismayani ${ }^{2}$ \\ ${ }^{1,2}$ Master of Management Program, Universitas Pembangunan Panca Budi, Medan, Indonesia, 20122 \\ Corresponding Author: Yohny Anwar
}

\section{ABSTRACT}

This study aims to find out and analyze the influence of internal and external factors on the quality of the annual development plan of the region in Aceh Tamiang Regency partially and simultaneously. The sample of this study is that all employees in the office of Regional Development Planning, Research and Development Agency (BAPPEDA) Aceh Tamiang district numbered 30 people. The results of the study obtained mathematical equations that are $\mathrm{Y}=9.468+0.262 \mathrm{X} 1+0.215$ $\mathrm{X} 2$. The correlation coefficient value $(\mathrm{R})$ of 0.673 means a strong and positive relationship and significant (real) between internal and external factors with the quality of the regional annual development plan in Aceh Tamiang Regency. The coefficient of determination (R2) of 0.453 or $45.3 \%$ indicates that $45.3 \%$ of the quality of the regional annual development plan in Aceh Tamiang Regency is influenced by internal and external factors. The remaining $54.7 \%$ was influenced by other factors. $\mathrm{T}$ test results for internal factors $t$ calculated $>\mathrm{t}$ table value of $2,277>2.05183$ and significant in $\square=$ 0.05 obtained figures of $0.031<0.05$ means internal factors significantly affect the quality of the regional annual development plan in Aceh Tamiang District, which is the contribution of the variable of 0.262. External factors have a $t$ count value of $>t$ table and a significant $t$ that is far from the significant value of tolerance of 5\% which is $2,155>2.05183$ and significant 0.040 $<0.05$ and the contribution of these factors is the amount of the regression value with the number 0.215 . $F$ is worth 3.35 . The calculated $F$ value is above $F$ table which is $11,160>3.35$ and also the significant $F$ value is $0.000<0.005$.
\end{abstract}

So that from the results of the $F$ test can be analyzed that internal and external factors together the two free variables have a significant and significant / tangible effect on the quality of the annual development plan of the region in Aceh Tamiang District. Thus, the hypothesis that reads internal and external factors simultaneously affects the quality of the annual development plan of Aceh Tamiang District can be accepted and theoretically proven.

Keywords: Internal Factors, External Factors, Quality of Regional Annual Development Plans

\section{INTRODUCTION}

Development Planning is an important process to determine future actions in the implementation of development in the area. By using planning, it is expected that the implementation of development can achieve the desired results. An important factor in development planning is the courage to decide what to do, then when to do it, next how to do it and lastly who does it. Good planning can be achieved taking into account the conditions in the future. Good planning will also result in good decisions or results as well. In the implementation efforts One of the problems in development planning is the quality problem. A quality planning process will result in a quality plan. A quality plan will tend to accommodate the interests of various parties related to the implementation of a plan. Likewise, what often happens in the process of drafting a development plan, quality often does not get adequate 
attention, so it will result in a plan that is not qualified. BAPPEDA as an institution responsible for the development process in the region, of course not only conducting activities to prepare "how to plan a good development", but also how the process of implementation, supervision, and evaluation can run well. This is because the good development planning process should pay attention to the implementation, supervision and evaluation of regional development in previous years. Related to this, a strategy is needed to improve the planning process, implementation, supervision and evaluation of regional development in accordance with the quality standards of planning. In an effort to improve the quality of the annual development plan many factors are influencing, so to improve the quality of the annual development plan those factors must be identified for later found solutions to improve the quality of the factors that affect so as to produce a quality annual development plan.

\section{LITERATURE REVIEW 1. Quality}

Quality is the overall characteristic and nature of a product or service that affects its ability to satisfy the stated or implied needs. According to Garpersz (2014:5), quality is defined as the totality of the characteristics of a product that supports its ability to satisfy specified or defined needs. Quality is often interpreted as customer satisfaction or conformance to the requirement.

According to Nirwana (2014:86) SERVQUAL dimensions (service quality dimensions) consists of several dimensions, including:

\section{a. Tangible}

Tangible or physical evidence is the ability of the company in showing its existence. For example, warehouses, technology facilities, employee appearance, and so on that emphasize more on the evidence isik, or can be touched its existence.

\section{b. Reliability}

Reliability which includes reliability is the company's ability to provide services that are in accordance with what is promised to customers. This can be a performance improvement that is in line with customer expectations.

\section{c. Responsiveness}

Responsiveness or response owned by employees and company leaders. The Company must demonstrate its ability to provide fast and precise service to customers if the customer is in need of the intended service.

\section{d. Assurance}

It is a form of guarantee and certainty of services offered. This is related to the knowledge and ability of employees in fostering customer trust in the company. In it there are elements of employee ethics, employee credibility, customer security.

\section{e. Empathy}

It is an individual attention to the company's customers. This is so that the company can understand further the wants and needs of its customers.

\section{Plan}

The plan is the result of the planning process in the form of a list of provisions on future action measures concerning what activities, who is the executor, where, when the schedule and how many resources will be used, as well as various information about the benchmarks, in order to achieve results. The plan is used by management for activity direction guidelines and also as a guideline for the control process (Wikipedia, 2018).

\section{Planning}

Planning is a decision-making activity of a number of choices regarding the objectives and ways that will be implemented in the future in order to achieve the desired goals, as well as the 
intermediation and assessment of the development of the results of its implementation that will be carried out systematically and continuously (Solihin, 2002:14)

According to Solihin (2008) there are 6 (six) planning functions: 1. Planning is expected to be a guideline for the implementation of activities indicated to achieve certain objectives. 2. Planning makes the process of achieving goals more targeted. 3. Planning can estimate the things that will be passed. 4. Planning gives you the opportunity to choose the best combination of ways. 5. Planning is done based on the priority scale (objectives, objectives, and actions. 6. With planning, there will be a measuring instrument to conduct evaluation.

\section{Development}

Siagian (2010:9) gives an understanding of development as "A business or series of growth and change efforts that are planned and carried out consciously by a nation, state and government, towards modernity in the framework of nation building". While Trijono, 2007:3) Development is an effort to meet basic human needs, both individually and in groups, in ways that do not cause damage. Development is also defined as a process of social change with extensive participatory in a society intended to achieve social and material progress (including increased fairness, freedom and other cherished qualities) for the majority of the people through greater control over their environment.

\section{Development Planning}

In accordance with Law No. 25 of 2004, on the National Development Planning System, development planning is a unified action to produce development plans in the long, medium and yearly implementation by state and community organizers at the central and regional levels. Development planning consists of four (4) stages, namely: (1) the preparation of plans;
(2) determination of the plan; (3) control over the implementation of the plan; and (4) evaluation of the implementation of the plan.

According to Solihin (2002:15), when drawing up a development plan, there are five main things that need attention, namely the following: a. Problems and potentials that exist $b$. Goals and objectives to be achieved c. Wisdom and ways to achieve goals and objectives etrasebut $d$. Translation of plans into real forms of programs e. The period of achievement of the goal.

\section{Annual Development Plan}

According to the Regulation of the Minister of Home Affairs Number: 86 of 2017 concerning Procedures for Planning, Controlling and Evaluating Regional Development, Procedures for Evaluation of Draft Regional Regulations on Regional Long-Term Development Plans and Regional Medium-Term Development Plans, as well as Procedures for Changes in Regional Long-Term Development Plans, Regional Medium-Term Development Plans, and Regional Government Work Plans. It is mentioned that the Annual Development Plan hereinafter referred to as the Local Government Work Plan hereinafter abbreviated as RKPD is a regional planning document for a period of 1 (one) year.

7. Regional Development Planning Agency Establishment of Regional Development Planning Agency (BAPPEDA) of the Republic of Indonesia is began from the enactment of presidential decree No. 27 of 1980 concerning the Establishment of BAPPEDA R.I. In the Presidential Decree No. 27 of 1980 explained that BAPPEDA has two levels of position, namely BAPPEDA level I (Provincial Government) and BAPPEDA level II (District Government / City).

8. Kamelus Annual Planning and Budgeting Process (2004: 35) states to improve the 
effectiveness and efficiency of regional planning and budgeting, it is necessary to improve the planning and budgeting process, among others related to the flow of planning and budgeting processes and the system of drafting planning and budgeting documents must be consistent.

9. Quality of Regional Annual Development Plan according to Keban (2001: 10) gives its statement as follows: "Content, process and context are parameters that are often used to measure the quality of a strategic plan. A strategic plan can be considered good quality if the contents of the document describe the aspirations and will of the stake holders, the quality of the document can also be assessed from the process taken or the method used whether in accordance with existing scientific procedures". According to Solihin (2008), planning requirements must be: (a) factual and realistic, which refers to the existing dynamics (b) logical and rational, i.e. reasonable and understandable planning, (c) flexible, i.e. flexible plans with attention to constraints and limitations of the social and physical environment, (d) objectives, i.e. fulfilling commitments to the public interest (e) comprehensive or comprehensive.

10. Factors That Affect the Quality of the Annual Development Plan of Aceh Tamiang Regency The factors that affect it are: (1) internal factors in the form of human resources; (2) external factors consisting of: Regent as Regional Head, relationship with SKPD, Relationship with DPRD, and community participation. Of these factors the most influential are human resource factors and community participation (Sahdi, 2012:65). According to the opinion issued by the State Administration Agency (LAN) and Deutsche Stiftung Fur Internationale Entwicklung (DSE) as set forth in the Regional Development Planning Training Module (Riyadi and Deddy, 2003:28), things that can affect regional development planning include:

a. Political stability and domestic security. b. Performed by people who are experts in their fields.

c. Realistic, in accordance with the capabilities of resources and funds.

d. Good coordination.

e. Top down and bottom up planning.

f. Continuous monitoring and monitoring system.

g. Transparency and acceptable to the public.

Factors that can affect development include:

a. Environmental Factors include:

1. Social

2. Culture

3. Economy

4. Politics

b. Human Resource Factor Planner A planner must have management-oriented qualifications that concern the four main stages of planner, namely:

1. Regional analysis

2. Development prospects

3. Planning and program creation

4. Implementing plans, monitoring and evaluation.

c. System Factors Used

d. Development factors of Science and Technology In relation to development issues, science and technology become important factors and play a very big role for the achievement efforts. Based on historical experience, the development of science and technology began to have a great influence on the development process during the revolution in England in the 18th century. Since then there has been a very rapid development in the field of development studies with a variety of studies.

e. Funding Factors

The funding factor is basically a factor that has been given. That is, it must be there to do an activity or activity. One, however, that in the process of planning regional development should be really considered as a very important thing. Regional development planning is an 
"expensive" activity. Therefore, the implementation must be really serious, in the sense that the relevant parties including the planners must focus on their duties, have a commitment to the goals to be achieved and must work hard, thoroughly and not rush in the preparation.

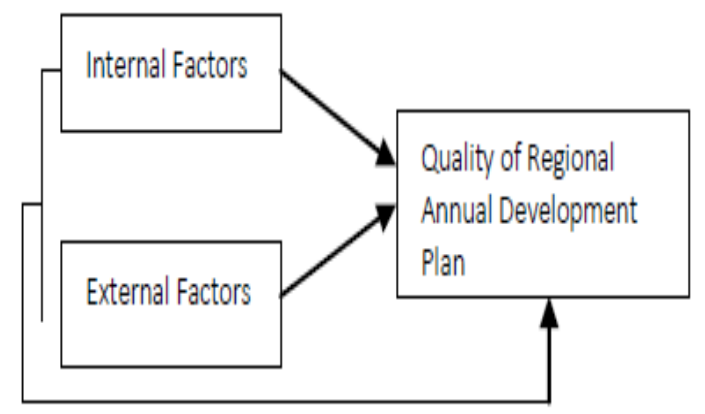

Figure 1 Conceptual Framework

$\mathrm{X} 1=$ Internal Factors

$\mathrm{X} 2=$ External Factors

Y1 = Quality Of Development Plan Annual Region

\section{Hypothesis}

Based on conceptual framework, the hypotheses in this study:

1. Partially there is an influence of internal and external factors on the quality of the annual development plan of Aceh Tamiang Regency

2. Simultaneously there are influences of internal and external factors on the quality of the annual development plan of Aceh Tamiang Regency

\section{METHODOLOGY}

This research was conducted using the approach of survey method, which is the activity of collecting data on facts that are supporters of research, with the intention to know the status, symptoms, determine the similarity of status by comparing with the standards that have been selected and or determined (Arikunto, 2013).

The population in this study is all Civil Servants in BAPPEDA Aceh Tamiang Regency, Regional Device Parties / Agencies, Members of the DPRK Aceh Tamiang related in the preparation of the annual development plan which is then called respondents. Sampling techniques in this study use saturated/census sample techniques. According to Effendi and Tukiran (2014:135), saturated samples are a sampling method when all members of the population are taken as sample members.

Table 1: Sample Amount

Table 1: Sample Amount
\begin{tabular}{|l|l|}
\hline Section & Amount \\
\hline DPRK members & 1 \\
\hline Head of Service & 1 \\
\hline Secretary Bappeda & 1 \\
\hline Head of Bappeda & 4 \\
\hline Head of Bappeda Sub Division) & 3 \\
\hline Member of Head of Bappeda Sub-Division & 10 \\
\hline Bappeda Executor/Staff & 10 \\
\hline Total Source: BAPPEDA Aceh Tamiang Regency & 30 \\
\hline
\end{tabular}

RESULTS

Validity Test

Table 2: Internal Factors Validity Test

\begin{tabular}{|l|l|l|l|}
\hline No & $\begin{array}{l}\text { Internal } \\
\text { Factors }\end{array}$ & $\begin{array}{l}\text { Corrected Item-Total } \\
\text { correlation }\end{array}$ & Descriptions \\
\hline 1 & FI 1 & 0,423 & Valid \\
\hline 2 & FI 2 & 0,381 & Valid \\
\hline 3 & FI 3 & 0,519 & Valid \\
\hline 4 & FI 4 & 0,400 & Valid \\
\hline 5 & FI 5 & 0,475 & Valid \\
\hline 6 & FI 6 & 0,548 & Valid \\
\hline 7 & FI 7 & 0,589 & Valid \\
\hline 8 & FI 8 & 0,479 & Valid \\
\hline 9 & FI 9 & 0,562 & Valid \\
\hline 10 & FI 10 & 0,606 & Valid \\
\hline 11 & FI 11 & 0,512 & Valid \\
\hline
\end{tabular}

Internal Factor validity test results have a value greater than 0.3610 , according to Sugiyono (2009:179) If $r>0.30$, then the question items from the questionnaire are valid and can be used in further research.

Table 3: External Factors Validity Test

\begin{tabular}{|l|l|l|l|}
\hline No & $\begin{array}{l}\text { External } \\
\text { Factors }\end{array}$ & $\begin{array}{l}\text { Corrected Item-Total } \\
\text { correlation }\end{array}$ & Descriptions \\
\hline 1 & FE 1 & 0,563 & Valid \\
\hline 2 & FE 2 & 0,596 & Valid \\
\hline 3 & FE 3 & 0,514 & Valid \\
\hline 4 & FE 4 & 0,643 & Valid \\
\hline 5 & FE 5 & 0,594 & Valid \\
\hline 6 & FE 6 & 0,571 & Valid \\
\hline 7 & FE 7 & 0,565 & Valid \\
\hline 8 & FE 8 & 0,542 & Valid \\
\hline 9 & FE 9 & 0,682 & Valid \\
\hline 10 & FE 10 & 0,684 & Valid \\
\hline 11 & FE1 1 & 0,484 & Valid \\
\hline 12 & FE 12 & 0,531 & Valid \\
\hline 13 & FE 13 & 0,639 & Valid \\
\hline 14 & FE 14 & 0,482 & Valid \\
\hline 15 & FE 15 & 0,546 & Valid \\
\hline 16 & FE 16 & 0,499 & Valid \\
\hline
\end{tabular}

Source: Research Result, 2019 (Data Processed). 
External Factor validity test results have a value greater than 0.3610 , according to Sugiyono (2009:179) If $r>0.30$, then the question items from the questionnaire are valid and can be used in further research.

Table 4: Quality Validity Test of Regional Annual Development Plan (KRP)

\begin{tabular}{|l|l|l|l|}
\hline No & $\begin{array}{l}\text { KRP } \\
\text { Factors }\end{array}$ & $\begin{array}{l}\text { Corrected Item-Total } \\
\text { correlation }\end{array}$ & Descriptions \\
\hline 1 & KRP 1 & 0,620 & Valid \\
\hline 2 & KRP 2 & 0,756 & Valid \\
\hline 3 & KRP 3 & 0,526 & Valid \\
\hline 4 & KRP 4 & 0,491 & Valid \\
\hline 5 & KRP 5 & 0,387 & Valid \\
\hline 6 & KRP 6 & 0,547 & Valid \\
\hline 7 & KRP 7 & 0,635 & Valid \\
\hline 8 & KRP 8 & 0,562 & Valid \\
\hline 9 & KRP 9 & 0,526 & Valid \\
\hline \multicolumn{3}{|l|}{ Source: Research Result, 2019 (Data Processed). }
\end{tabular}

The results of the Quality test of the Regional Annual Development Plan have a value greater than 0.3610 , according to Sugiyono (2009:179) If $r>0.30$, then the question items from the questionnaire are valid and can be used in further research.

\section{Reliability Test}

According to Sugiyono (2014:348)

"The reliability of an instrument is an instrument that when used several times to measure the same object, it will produce the same data

\begin{tabular}{l} 
Tabel 5: Reliability Test \\
\begin{tabular}{|l|l|c|l|}
\hline Variable & Cronbach's Alpha & N of Item & Description \\
\hline FI & 0,804 & 11 & Reliabel \\
\hline FE & 0,899 & 16 & Reliabel \\
\hline KRP & 0,842 & 9 & Reliabel \\
\hline
\end{tabular} \\
\hline
\end{tabular}

Reliability test results can be seen $r-$ result values for free variables and bound variables are above the r-table value of 0.60 which indicates that the reliability level and can be used in subsequent studies.

\section{HYPOTHESIS TESTING}

\section{Partial Test Result (t Test)}

Tabel 6: Coefficients ${ }^{\mathrm{a}}$

\begin{tabular}{|l|l|l|l|l|l|}
\hline \multirow{2}{*}{ Model } & \multicolumn{2}{|l|}{ Unstandardized Coefficients } & Standardized Coefficients & \multirow{2}{*}{ sig } \\
\cline { 2 - 6 } & B & Std. Error & Beta & 1.680 & .104 \\
\hline 1 Constant & 9.468 & 5.634 & & 2.277 & .031 \\
\hline FI & .262 & .115 & .391 & 2.155 & 040 \\
\hline FE & .215 & .100 & .370 & Source: Research Result, 2019 (Data Processed)
\end{tabular}

The coefficient of regression of internal factors amounted to 0.262 with a calculated $\mathrm{t}$ value of $>\mathrm{t}$ table of 2,277 > 2.05183 and significantly in $p=0.05$ obtained the figure of $0.031<0.05$ means that internal factors significantly affect the quality of regional annual development plans in Aceh Tamiang Regency, which is the contribution of the variable of 0.262 . This means that if there is an increase in internal factors, it will also increase the quality of the regional annual development plan. Thus the hypothesis that reads internal factors partially affects the quality of the annual development plan of Aceh Tamiang district is acceptable and theoretically proven.

The value of the coefficient External factors to the quality of the annual development plan of Aceh Tamiang District, amounted to 0.215 . This value can be accounted for statistically and significantly. The point is that the value has a $t$ count greater than the table $t$ and a significant $t$ that is far from the significant value of tolerance of $5 \%$ which is $2,155>2.05183$ and significant $0.040<0.05$. So it can be analyzed that external factors have a positive and significant effect on the quality of the regional annual development plan in Aceh Tamiang District and the contribution of these factors is the amount of the regression coefficient value with the figure of 0.215

\section{Simultaneous Test Results (Test F)}

The calculated $F$ value is above the table $F$ which is $11,160>3.35$ and also a significant $F$ value that is far from a significant tolerance level of $5 \%$, which is 
$0.000<0.005$. So that from the results of the $F$ test can be analyzed that internal and external factors together the two free variables have a significant and significant / tangible effect on the quality of the annual development plan of the region in Aceh
Tamiang Regency. Thus, the hypothesis that reads internal and external factors simultaneously affects the quality of the annual development plan of Aceh Tamiang District can be accepted and theoretically proven.

\begin{tabular}{|} 
Table 7: ANOVA \\
\begin{tabular}{|l|l|l|l|l|l|}
\hline Model & Sum of Square & df & Mean Square & F & sig \\
\hline Regression & 321.066 & 2 & 160.533 & 11.160 & $.000 \mathrm{a}$ \\
\hline Residual & 388.401 & 27 & 14.385 & & \\
\hline Total & 709.467 & 29 & & & \\
\hline
\end{tabular} \\
\hline
\end{tabular}

The results of this study are in line with the strategy in BAPPEDA Aceh Tamiang Regency, namely by implementing various alternative options related to regional development based on the selection of strategic issues in determining the priority of activities and this becomes a mandate and fundamental challenges faced by BAPPEDA in improving its performance. Strategic issues faced by BAPPEDA can occur due to changes in the external and internal environment.

This research is not in line with research conducted by Asin (2014), where factors that can influence the success rate of a regional development planning program by referring to factors that can affect development include: 1) environmental factors consisting of external and internal factors, which can include social, cultural, and political fields. As already stated, the environment has a strong influence on the success of regional development planning programs. Environmental factors can come from outside (external) and from the inside (internal). External factors usually come from neighbouring regions or global influences that develop in the national and international sphere. While internal factors are influences that come from within the planning area itself. 2) Human resource planning factors. Where good quality planning will be more likely to be created by the right human resources and quality, while good planning is also more likely to be implemented in development programs. Thus, the quality of good planning depends on the ability, expertise, and flexibility by the planners in addition to the techniques and methods used.

\section{DISCUSSION}

1. The influence of internal factors on the quality of the annual development plan as revealed by Slamet (2003:137-143) Internal factors are derived from the community itself, namely individuals and the unity of the group in it. Individual behaviour is closely related or determined by sociological traits such as age, gender, knowledge, occupation or income. One of the obstacles in planning is limited human resources. The level of education is an indicator of the measurement of the ability of employees and the ability obtained from the level of employee education and give a pattern to the implementation of tasks and functions of the organization, because the higher the level of education owned by employees will be effective and efficient in carrying out their duties and functions to achieve the objectives.

2. The influence of external factors on the quality of the annual development plan according to Sunarti (in the journal Loka, 2003:9) can be said bettors (stakeholders), namely In this case stakeholders who have an interest in this program are the local government, village government, community leaders / indigenous and consultants / facility. In the determination of the Regional Regulation on RKPD regional development planning agency only provides the results of the final drafting 
of the RKPD to the Regent of Aceh Tamiang. And then the Regent will draft the Regional Regulation and ratify the RKPD. It will also be reviewed by the Legislature /DPRD before the plenary hearing. Where according to the results of interviews with informants that RKPD will be reviewed so as not to violate the rules and ordinances in the determination of RKPD. Because of the passing of the RKPD without discussion at the legislative level, so that it reaches the plenary session of the DPRK Aceh Tamiang, is the result of the agreement of members of the Legislative Body when holding a meeting in the room of one of the leaders of the DPRK Aceh Tamiang. Based on the results of research on the relationship with the regent as a regional coconut and the relationship with the legislature supports each other and follows the planning flow.

3. Community participation in the decision-making process is very important for the community because the community can express opinions and determine what decisions or policies will be decided and that are in accordance with the wants or needs of the community. In that case, the community is freed to give proposals or ideas, suggestions and criticisms about village development planning by means of meetings or meetings held between the community and the government. Community participation in development planning is in MUSRENBANG village, MUSRENBANG sub-district and MUSRENBANG district. From the results of research conducted community participation is very active and enthusiastic in planning, this can be seen in the forum MUSRENBANG village, sub-district or district community is always present and active in delivering proposed programs / activities.

\section{CONCLUSION}

a. Internal and external factors have a partial positive and significant effect on the quality of the regional annual development plan in Aceh Tamiang Regency.

b. Internal and external factors have a positive and significant effect simultaneously on the quality of the annual development plan of the region in Aceh Tamiang Regency.

Acknowledgement: None

\section{Conflict of Interest: None}

\section{Source of Funding: None}

\section{REFERENCES}

1. Arikunto, Suharsimi. (2013). Prosedur Penelitian: Suatu Pendekatan Praktik. Edisi Revisi. Cetakan Kedelapan. Jakarta: Rineka Cipta.

2. Azwar, Saifuddin. (2007). Metode Penelitian. Yogyakarta: Pustaka Pelajar.

3. Churchill, Gilbert, A. Jr. (2002). Dasardasar Riset Pemasaran. Translated: Dwi Kartini Yahya. Jakarta: Erlangga.

4. Darwanto H. (2003). Membangun Wilayah yang Produktif, Direktur Pengembangan Kawasan Khusus dan Tertinggal. Jakarta: Bappenas.

5. Dewi, Sawitri. Manusia dalan Pengembangan Wilayah Berbasis Sumberdaya Lokal", (2004). Access on http://lib.itenas.ac.id/jurnal/volume8.

6. Effendi, Sofian, dan Tukiran, (2014), Metode Penelitian Survei, LP3S, Jakarta.

7. Ghozali, Imam. (2011). Aplikasi Analisis Multivariate Dengan Program SPSS. Semarang: Badan Penerbit Universitas Diponegoro.

8. Iqbal, Muhammad. (2012). Pelayanan yang Memuaskan: Kisah Refleksi, Arti, Strategi, SDM, dan Benang Merah Pelayanan. Jakarta: Elex Media Computindo.

9. Mardiasmo. (2006). Pewujudan Transparansi dan Akuntabilitas Publik Melalui Akuntansi Sektor Publik: Suatu Sarana Good Governace. Jurnal Akuntansi Pemerintahan Vol. 2, No.1, Mei 2006

10. M.Sinaga Anggiat dan Sri Hadiati. (2001). Pemberdayaan Sumber Daya Manusia 
Jakarta: Lembaga Administarsi Negara Republik Indonesia.

11. Munir, B, (2002), Perencanaan Pembangunan Daerah Dalam Perspektif Otonomi Daerah, Badan Penerbit BAPPEDA, Nusa Tenggara Barat.

12. Nirwana. (2014). Service Marketing Strategy. Malang: Dioma. Nugroho, Bhuono A. (2005). Strategi jitu memilih metode statistik penelitian dengan SPSS. Yogyakarta: Penerbit Andi.

13. Prasetyo, Bambang (2006). Metode Penelitian Kuantitatif: Teori dan Aplikasi. Raja Grafindo Persada: Jakarta.

14. Riyadi dan Deddy Supriyadi Bratakusumah, (2005). Perencanaan Pembangunan Daerah. Jakarta: PT Gramedia Pustaka Utama

15. Siagian, Sondang P. (2010). Administrasi Pembangunan: Konsep, Dimensi, dan Strateginya. Penerbit PT Bumi Aksara: Jakarta.

16. Solihin, Dadang. (2002). Proses pengambilan Keputusan Perencanaan, disampaikan pada kursus Tehnik dan Manajemen Perencanaan Pembangunan Tingkat Dasar Angkatan ke-28 Pendidikan dan Latihan LPEM-FE Universitas Indonesia: Jakarta.

17. Sugiyono. (2014). Metode Penelitian Bisnis. Cetakan Kesembilan. Bandung: Alfabeta.

18. Supranto, J. (2012). Statistik Teori dan Aplikasi. Edisi I. Jilid I. Jakarta: Erlangga

19. Supriyadi, Ery. (2007). Telaah Kendala Penerapan Pengembangan Ekonomi Lokal: Pragmatisme dalam pendekatan PEL dalam jurnal PWK Vol.18 No.2 Agustus 2007 Hal. 103 - 123. PWK-ITB: Bandung.

20. Tjiptono, Fandy. (2014). Manajemen Jasa. Yogyakarta: ANDI.

21. Trijono, Lambang. (2007). Pembangunan Sebagai Perdamaian. Jakarta: Yayasan Obor Indonesia.

22. Umar, Husein. (2013), Metode Penelitian untuk Skripsi dan Tesis. Jakarta: RajawaliArafat, Yaser, 2002. Evaluasi Kinerja Kabupaten Barito Utara pada Proses Penyusunan Perencanaan Pembangunan Tahunan Daerah Universitas Dipenogoro, Semarang.

23. Sunarti (2003) Partisipasi Masyarakat Dalam Pembangunan Perumahan Secara Berkelompok. Jurnal Tata Loka, Universitas Dipenogoro, Semarang.

24. Syaifullah, 2008. Analisis Perencanaan Pembangunan Tahunan Daerah di Kota Magelang (Studi Kasus Perencanaan Pembangunan Tahun 2007), Tesis, Program Pasca Sarjana Universitas Diponegoro Semarang.

25. Sahdi, Mukhlisin, 2012. Proses Penyusunan Rencana Pembangunan Tahunan Daerah Di Daerah Baru (Kasus di Kabupaten Sumbawa Barat), Universitas Gadjah Mada, Yogyakarta.

How to cite this article: Anwar Y, Ismayani. Analysis of factors affecting the quality of the annual development plan of Aceh Tamiang Regency. International Journal of Research and Review. 2021; 8(5): 458-466. DOI: https://doi. org/10.52403/ijrr.20210556 